\title{
Editorial
}

\section{The enlargement of the European Union and financial services}

1st May, 2004, was one of the most significant dates in European Union (EU) history, due to the expansion of its membership from 15 to 25 states. ${ }^{1}$ The unprecedented number of new members joining the EU are Cyprus, the Czech Republic, Estonia, Hungary, Latvia, Lithuania, Malta, Poland, Slovakia and Slovenia. The enlargement of the EU is said to be 'a win-win game' as it provides reciprocal benefits to both existing and new member states, in terms of, inter alia, political and economic prosperity. This process of enlargement is the beginning of significant expansion that may see other European neighbours such as Bulgaria, Romania and Turkey joining the most powerful trading block in the world. ${ }^{2}$ The new members have to travel the road of considerable political, economic and constitutional reform. The negotiations at the Copenhagen European Council in 1993 (The Copenhagen Criteria) initiated and set out the principles of accession for those countries that 'desired' membership of the EU. The Copenhagen Criteria encapsulate the constitutional principles of the founding treaties of the EU, namely the Rome Treaty, the Maastricht Treaty and Treaty of Amsterdam. The principles that the prospective countries need to comply with are as follows:

- stability of institutions guaranteeing democracy, rule of law, human rights and the respect for and protection of minorities;
- the existence of a functioning market economy as well as the capacity to cope with competitive pressure and market forces within the Union;

- ability to take on the obligations of membership, including adherence to the aims of the political, economic and monetary union.

The new members have had to embark on an extensive programme of adopting and implementing the volumes of EU law into their domestic jurisdictions, touching upon all facets of both public and private affairs to achieve the criteria for membership. The new members have adopted and are implementing the acquis communautaire (community rights), which consist of 31 chapters and cover the main tenets of EU policy, such as the principles of free movement of goods, services and people to name just a few. ${ }^{3}$ The agenda for the monitoring of the whole process of accession was set out at the Madrid European Council in 1995, where the necessity for appropriate administrative and judicial structures to be in place ensure that membership is effective on the date of accession. Subsequently, the Helsinki European Council concluded that the process of negotiation and incorporation of the acquis needed to be coordinated to make sure EU laws were enforced effectively in new members' jurisdictions.

The European Commission monitored the progress made by the prospective countries and judged their compliance to gauge whether areas required further 
attention. These findings have formed part of the 'Regular Reports' submitted by the Commission to the Council of the EU. ${ }^{4}$ It comes as no surprise that not all of the provisions in the chapters of the acquis were implemented by the time the accession date arrived. The Commission, under three broad categories, has measured the readiness of compliance: the first category indicates that the country is compliant, subject to some minor issues of non-compliance being rectified. The second category indicates that the country is required to 'enhance efforts' to make sure it is compliant by the time it joins. The third category refers to more serious concerns, where the country is required to take 'immediate and decisive action' to rectify problems. The EU has negotiated transitional arrangements, 'limited in terms of time and scope', where the acceding states have not fully complied with the acquis. This is with the caveat that the measures do not, inter alia, amend or disrupt the proper function of the EU's respective rules. The implementation of the acquis has also required, inevitably, changes to the administrative infrastructure in the countries so that there is an effective civil service and a judiciary that is devoid of corruption.

The financial services sector in the EU is the sum of a number of discrete parts. The sector's efficiency is affected directly and indirectly by many of the chapters of the acquis, the most significant chapters being Chapter 3 on the freedom to provide services, ${ }^{5}$ Chapter 4 on the free movement of capital; ${ }^{6}$ and Chapter 11 on economic and monetary union. ${ }^{7}$ The financial services industry gives rise to a number of complex issues; therefore it should not come as a surprise that a number of transitional arrangements are in place to provide the respective countries with the time to achieve full compliance. It would be naïve to think that such a colossal task could be completed in a matter of a few years. More importantly, the main issue is not simply adopting the rules per se, but ensuring they are an integral part of the daily workings of the new member states.

The freedom to provide services is set out in Chapter 3 and incorporates the requirements pertaining to Arts $43 \mathrm{EC}$ and 49 EC which relate to the freedom of establishment and the freedom to provide services, respectively. These Articles of the EC Treaty provide the context for the provision of banking, investment, securities and insurance business within the single market. With respect to this part of the acquis, the Commission placed a significant amount of emphasis on member states to have in place the appropriate infrastructure to ensure that financial services are well regulated and supervised so that they operate efficiently. According to final assessment before accession, all of the new members have transitional arrangements in place governing part of the financial services sector in one form or another, and last well beyond the date of accession. In relation to Chapter 3 a significant proportion of the transitional arrangements is concerned with the coverage and sufficiency of deposit protection and/or investor compensation schemes. For instance, Cyprus needs to ensure by 2007 that its deposit insurance scheme covers foreign currency deposits in relation to its cooperative credit and savings societies. Poland is required to ensure that cooperative credit institutions are fully under the EU regulatory umbrella by 2007.

The free movement of capital is governed by Chapter 4 of the acquis pertaining to Art. 56 of the EC Treaty. This provision applies to both the payments and transfers of money over borders and also the transfer of ownership regarding assets and liabilities. A significant number of transitional arrangements are in place to protect real estate investment by foreigners, for example, and full compliance with provisions 
governing the prevention of money laundering is also a priority. A number of the new member states also have the possibility of extending the transitional arrangements if they invoke the safeguard clause. For instance, the Czech Republic has arrangements governing the acquisition of secondary residences in place, which could be extended by three years.

The new member states will not fulfil the criteria relating to the single currency for some time, although they will, postaccession, be involved in the economic and monetary union governed by Chapter 11 . This is partly due to the fact that a significant proportion of the rules governing the single market, integral to monetary union, will not be fully operational until the transitional arrangements have elapsed. Furthermore, the new member states will need, inter alia, to complete the report on their financial position and their sustainability and participate in the exchange rate mechanism (ERM), where their currency will be pegged to the euro. It will be only after at least two years' membership of the ERM that the conditions for adopting the euro can be assessed. The full commitment to the euro would entail observance of the convergence criteria. Government deficits in relation to gross domestic product (GDP) have to be kept below 3 per cent. Public debt in relation to GDP should not exceed 60 per cent. The target for inflation is not allowed to be higher than 1.5 per cent above the lowest average between the three EU countries with the lowest inflation rate. Interest rates in the long term cannot be higher than 2 per cent above the rate between the three EU countries with the lowest inflation rate. The criteria for the single currency require a robust and efficient economic infrastructure to maintain compliance. Subsequently, the new member states have to ensure that membership of the single currency so soon after accession is economically beneficial, considering their stage of economic development where higher level of government investment would inevitably lead to higher levels of debt.

\section{Dr Dalvinder Singh \\ Senior Lecturer in Law Oxford Brookes University \\ IALS Editor \\ May 2004}

\section{References}

(1) For information about EU enlargement, see information posted at http://europa.eu.int/pol/enlarg/index_en.htm; for background see http://europa.eu.int/ comm/enlargement/communication/pdf/ explaining_enlargement.pdf.

(2) For an overview, see http://europa.eu.int/ comm/enlargement/docs/pdf/corpusen.pdf.

(3) The Chapters of the acquis are listed on http://europa.eu.int/comm/enlargement/ overview.htm.

(4) Comprehensive monitoring reports of the European Commission on the state of preparedness for EU membership of the Czech Republic, Estonia, Cyprus, Lativa, Lithuania, Hungary, Malta, Poland, Slovenia and Slovakia, http://europa.eu.int/comm/enlargement/ report_2003/pdf/summary_paper2003_full_en.pdf.

(5) http://europa.eu.int/comm/enlargement/ negotiations/chapters/chap3/index.htm.

(6) http://europa.eu.int/comm/enlargement/ negotiations/chapters/chap4/index.htm.

(7) http://europa.eu.int/comm/enlargement/ negotiations/chapters/chap11/index.htm. 